J. Clin. Chem. Clin. Biochem.

Vol. 24, 1986, pp. 325-331

(C) 1986 Walter de Gruyter \& Co. Berlin - New York

\title{
Liquid Chromatographic Determination of Ciprofloxacin and Some Metabolites in Human Body Fluids
}

\author{
By $K$. Borner \\ Institut für Klinische Chemie und Klinische Biochemie \\ H. Lode, G. Höffken, C. Prinzing, P. Glatzel and R. Wiley \\ Medizinische Klinik und Poliklinik Klinikum Steglitz der Freien Universität Berlin
}

(Received November 6, 1985/January 16, 1986)

Summary: Two column liquid chromatographic (HPLC) methods for the determination of ciprofloxacin and three metabolites are described. Both use reversed phase chromatography, the stationary phase being Nucleosil 5C18. Method A separates ciprofloxacin, metabolite M1 and another metabolite of unknown structure using fluorometric detection. Method B allows the determinations of metabolite M3 (oxo-ciprofloxacin) in urine by UV absorption. Serum was deproteinised with acetonitrile. Urine was diluted with buffer solution. The detection limit of ciprofloxacin was $0.010 \mathrm{mg} / 1$ serum and $0.2 \mathrm{mg} / 1$ urine and for the metabolite $\mathrm{M} 3,1 \mathrm{mg} / 1$ urine. Within-batch precision (coefficient of variation) for ciprofloxacin in serum was 0.8 to $2.4 \%$ and between-batch precision 4.8 to $9.3 \%$. In urine within-batch precision was 1.7 to $2.1 \%$ and between-batch precision 2.4 to $7.2 \%$. Recovery rates of ciprofloxacin from three groups of spiked sera was $94.5 \pm 2.6 \%$, $97.2 \pm 1.1 \%$ and $95.0 \pm 1.8 \%$ and from urine $99.6 \%$. Results obtained by HPLC (method A) were compared with those from a standard microbiological assay by means of bivariate regression analysis. In 12 subsets of data the slope of the regression line varied from 1.042 to 1.556. Significantly higher results from the microbiological assay were probably due to the presence of microbiologically active metabolites. We conclude that HPLC is the more specific method of determination. The described methods were applied for pharmacokinetic studies and therapeutic drug monitoring.

\section{Flüssigkeitschromatographische Bestimmung von Ciprofloxacin in menschlichen Körperflüssigkeiten}

Zusammenfassung: Es werden zwei säulenchromatographische Methoden (HPLC) zur Bestimmung von Ciprofloxacin und von drei Metaboliten beschrieben. Beide Methoden arbeiten nach dem Prinzip der reversed phase Chromatography. Die stationäre Phase ist Nucleosil 5C18. Methode A trennt Ciprofloxacin, Metabolit M1 und einen weiteren Metaboliten von bisher unbekannter Struktur und verwendet die Fluoreszenz zur Detektion. Methode B erlaubt die Bestimmung von Metabolit M3 (Oxo-ciprofloxacin) im Urin durch UV-Absorption. Serum wurde mit Acetonitril enteiweißt. Urin wurde mit Pufferlösung verdünnt. Die Nachweisgrenze von Ciprofloxacin war $0,01 \mathrm{mg} / 1$ Serum und $0,2 \mathrm{mg} / \mathrm{l}$ Urin. Die Nachweisgrenze von Metabolit M3 im Urin betrug $1 \mathrm{mg} / \mathrm{l}$. Die Präzision in Serie, ausgedrückt als Variationskoeffizient, betrug für Ciprofloxacin im Serum 0,8 bis $2,4 \%$ und die Präzision von Tag zu Tag 4,8 bis 9,3\%. Im Urin war die Präzision in Serie 1,7 bis 2,1\% und die Präzision von Tag zu Tag 2,4 bis 7,2\%. Die Wiederauffindung von Ciprofloxacin aus Serum war in drei Serien 94,5 $\pm 2,6 \%, 97,2 \pm 1,1 \%$ und 95,0 $\pm 1,8 \%$. Die Wiederauffindung aus Urin war $99,8 \%$. Ergebnisse der HPLC-Methode A wurden mit den Ergebnissen eines üblichen mikrobiologischen Așsays mit der bivariaten Regressionsanalyse verglichen. In 12 Daten-Gruppen variierte die Steigung der Regressionsgeraden von 1,042 bis 1,556. Die signifikant höheren Ergebnisse des Bioassays wurden vermutlich durch das Vorliegen von mikrobiologisch aktiven Metaboliten verursacht. Die HPLC ist unseres Erachtens die spezifischere Analysenmethode. Die beschriebenen HPLC-Methoden wurden zur Auswertung pharmakokinetischer Studien und im therapeutic drug monitoring eingesetzt. 


\section{Introduction}

Ciprofloxacin (1-cyclopropyl-6-fluoro-1,4-dihydro-4oxo-7-(1-piperazinyl-)-quinolone-3-carboxylic acid; fig. 1) belongs to the recent derivatives of nalidixic acid, called gyrase inhibitors. It has remarkable antimicrobial activity $(1-8)$ and is presently under clinical evaluation. This paper describes the determination of ciprofloxacin and three of its metabolites in human body fluids. The method has been extensively used in pharmacokinetic studies $(9-11)$ and for therapeutic drug monitoring.<smiles>O=C(O)c1cn(C2CC2)c2cc(N3CCNCC3)c(F)cc2c1=O</smiles>

Ciprofloxaciṇ(109867)<smiles></smiles>

$M 3$ (q 3542)

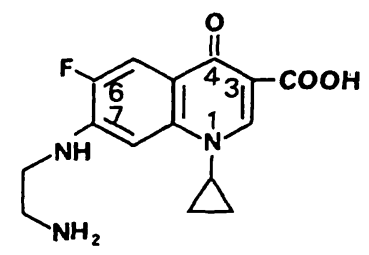

M1 (r 3964)

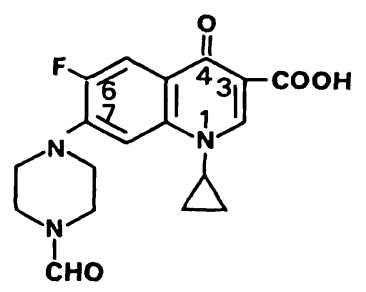

M4 (p9357)
Fig. 1. Chemical structure of ciprofloxacin and some metabolites.

\section{Methods}

Chemicals

Reference material of ciprofloxacin (lot no. 907452 , potency $842 \mathrm{mg} / \mathrm{g}$ ) and of several metabolites (cf. fig. 1) were kindly supplied by Bayer AG, Wuppertal, FRG. Tetrabutyl ammonium phosphate (PIC A, low UV grade) was obtained from Waters GmbH., Eschborn, FRG. Unless otherwise stated reagents and solvents were of reagent grade purity supplied by E. Merck AG, Darmstadt, FRG. Redistilled water was used in all experiments.

\section{Volunteers and patients}

Volunteers participating in pharmacokinetic studies were instructed not to take any drugs or caffeine- or quinine-containing beverages $24 \mathrm{~h}$ before and during the study. Patients were on a regular hospital diet and usually received 4 to 6 drugs concomitantly which were recorded for possible analytical interferences. All volunteers gave written informed consent according to legal requirements in the FRG.

Blood was taken without additives and was allowed to clot at room temperature. It was subsequently centrifuged at $3000 \mathrm{~g}$ for $10 \mathrm{~min}$. Serum and urine specimens for chromatography were stored at $-80^{\circ} \mathrm{C}$ for no more than 2 months before processing. The microbiological determination was performed on the day of sampling or on the day thereafter.

\section{Preparation of the mobile phase}

Solution of tetrabutyl ammonium phosphate: $5 \mathrm{mmol}$ tetrabutyl ammonium phosphate (1 vial PIC A, Waters) were dissolved in approximately $800 \mathrm{ml}$ water. The solution was adjusted to pH 2 with approximately $1.3 \mathrm{ml}$ concentrated phosphoric acid and made up to 11 .

if

\section{Method A}

$125 \mathrm{ml}$ acetonitrile were mixed with tetrabutyl ammonium phosphate solution and made up to a final volume of 11 .

\section{Method B}

$220 \mathrm{ml}$ acetonitrile were mixed with tetrabutyl ammonium phosphate solution and made up to a final volume of 11 .

The mobile phases were filtered before use and were recycled for no more than 3 days of continuous operation.

\section{Preparation of standards}

A stock solution of $10 \mathrm{mg} / 1$ ciprofloxacin was made by diluting $11.88 \mathrm{mg}$ of reference material in water. The stock solution was stable at $4{ }^{\circ} \mathrm{C}$ for at least 1 week. Working standards $(0.010$ to $3.000 \mathrm{mg} / \mathrm{l}$ ) were prepared daily by dilution of the stock standard with water. A standard solution of metabolite M3 was prepared by dissolving reference material in $0.5 \mathrm{ml} 0.1 \mathrm{~mol} / \mathrm{l}$ sodium hydroxide and further dilution with $5 \mathrm{mmol} / \mathrm{l}$ tetrabutyl ammonium phosphate solution. M1 was dissolved in $0.1 \mathrm{~mol} / 1$ hydrochloric acid.

\section{Processing of samples}

Urine was diluted with aqueous tetrabutyl ammonium phos: phate solution $1: 40$ to $1: 10000$ according to the expected concentration. Serum was deproteinised by mixing $0.3 \mathrm{ml}$ serum with $0.6 \mathrm{ml}$ acetonitrile. After centrifugation ( $2 \mathrm{~min}$ at $10000 \mathrm{~g}$ ) $0.3 \mathrm{ml}$ supernatant was diluted with $1.2 \mathrm{ml}$ aqueous tetrabutyl ammonium phosphate solution. Standard solutions were treated likewise. To measure the extraction rate $0.3 \mathrm{ml}$ drugfree serum was spiked with $0.1 \mathrm{ml}$ standard solution $(0.400$ $\mathrm{mg} / \mathrm{l})$ and processed as described before. For control of precision, serum and urine pools of various concentrations were prepared from material obtained from volunteers.

\section{High performance liquid chromatography (HPLC)}

The chromatograph consisted of the following modules: a pump (flow rate $1 \mathrm{ml} / \mathrm{min}$, pressure $15 \mathrm{MPa}$, model 2/1, Perkin Elmer, Überlingen, FRG); an automatic sampler (injection volume 20 $\mu l$ (urine) or $20 \mu \mathrm{l}$ or $50 \mu \mathrm{l}$ (serum), model LC 420, Perkin Elmer); a precolumn ( 4 by $40 \mathrm{~mm}$, Perisorb RP18, particle diameter 30-40 $\mu \mathrm{m}$, E. Merck); a reversed phase column operated at room temperature 4 by $125 \mathrm{~mm}$, Nucleosil $5 \dot{C} 18$, particle diameter $5 \mu \mathrm{m}$, Macherey \& Nagel, Düren); a fluorescence detector (excitation $275 \mathrm{~nm}$, emission cut-off $418 \mathrm{~nm}$, time constant 4-6s, model FS 970, Schoeffel GmbH, Karlsruhe); and an integrator (model 3390A, Hewlett Packard, Frankfurt). For method B a variable wavelength detector (lambda $280 \mathrm{~nm}$, model LC 85, Perkin Elmer) was used. Concentrations were calculated from peak areas. Serum results were corrected for extraction rate. In sera from patients an extraction ratio of 0.95 was assumed.

\section{Microbiological assay of ciprofloxacin}

A microbiological assay which served as comparison was performed with a standard agar plate diffussion technique (12). The test species was Klebsiella pnéumoniae ATCC 10031 for concentrations below $0.15 \mathrm{mg} / \mathrm{l}$ and Bacillus subtilis ATCC 6633 
for concentrations above $0.15 \mathrm{mg} / \mathrm{l}$. Samples and standards were assayed in triplicate. For qualitative detection of antimicrobial activity in chromatographic fractions a commercial test strip (Micur@ BT, Boehringer Mannheim, FRG) was used.

\section{Statistical calculations}

Bivariate regression analysis was performed as previously described (13).

\section{Results}

\section{Development of the method}

Ciprofloxacin showed a typical UV absorption spectrum with a maximum at $275 \mathrm{~nm}$. Upon excitation at $275 \mathrm{~nm}$ an intense blue fluorescence was observed with a maximum at $450 \mathrm{~nm}$. For determination of the parent compound and the metabolite M1 (cf. fig. 1) detection by fluorescence was used in method $A$. The main metabolite M3, however, yielded a very low fluorescence and it was therefore quantitated by
UV absorption in method B. The separation principle of both methods was reversed phase chromatography. Typical chromatograms from serum and urine show the separation of ciprofloxacin and the metabolites $\mathrm{M} 1$ and $\mathrm{m} 2$ from endogenous compounds by method A (fig. 2 and fig. 3). Addition of tetrabutyl ammonium phosphate to the mobile phase was essential to avoid tailing of the peaks. Retention times of fluorescent compounds encountered in monitoring ciprofloxacin therapy of patients are given in table 1 .

Only tyrosine eluted close to ciprofloxacin. However, a high serum concentration of $100 \mu \mathrm{mol} / 1$ tyrosine produced a detector response equivalent to only $3 \mu \mathrm{g} / \mathrm{l}$ ciprofloxacin. For the elution of M3, the main metabolite in urine, the concentration of acetonitrile in the mobile phase had to be increased. Typical chromatograms obtained by method B using UV detection are shown in figure 4. Peaks of ciprofloxacin and M1 were qualitatively identified in $1 \mathrm{ml}$

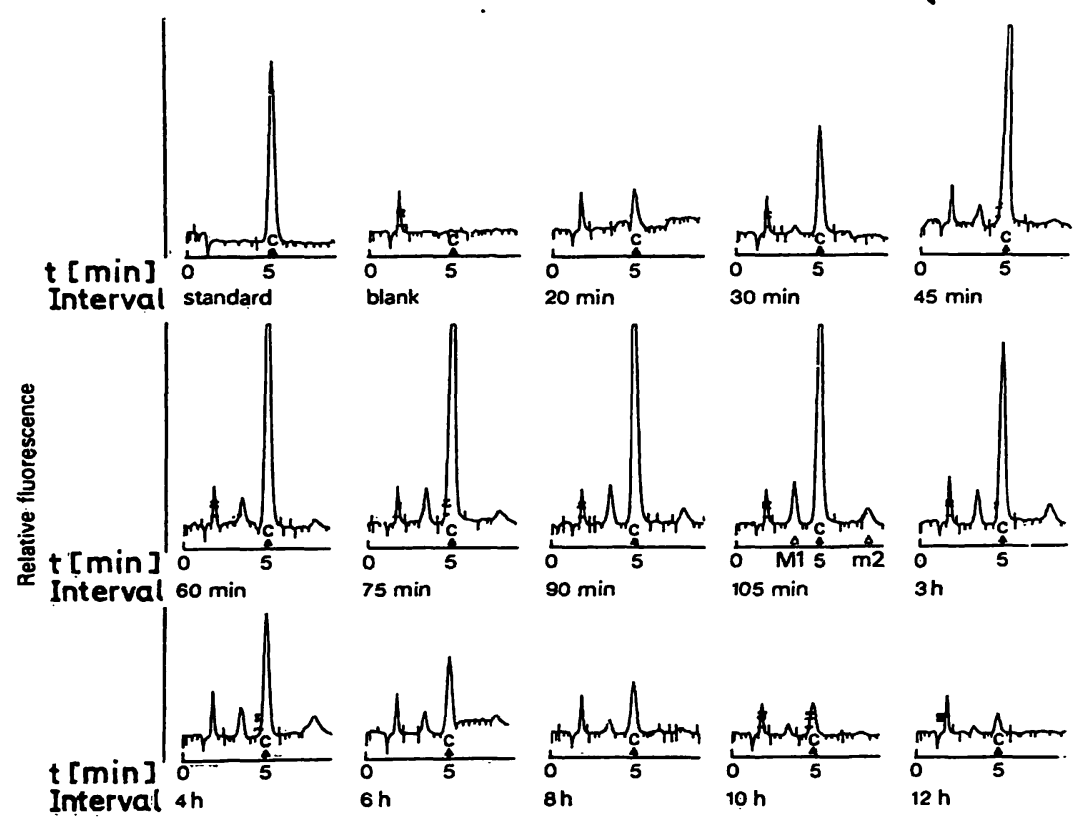

Fig. 2. Examples of chromatograms. Serum of a normal volunteer after a single oral dose of $750 \mathrm{mg}$ ciprofloxacin. Separation of ciprofloxacin (C), M1 and $m 2$ by method $A$.

$t=$ retention time; the interval indicated below each chromatogram refers to sampling time after intake of the drug.

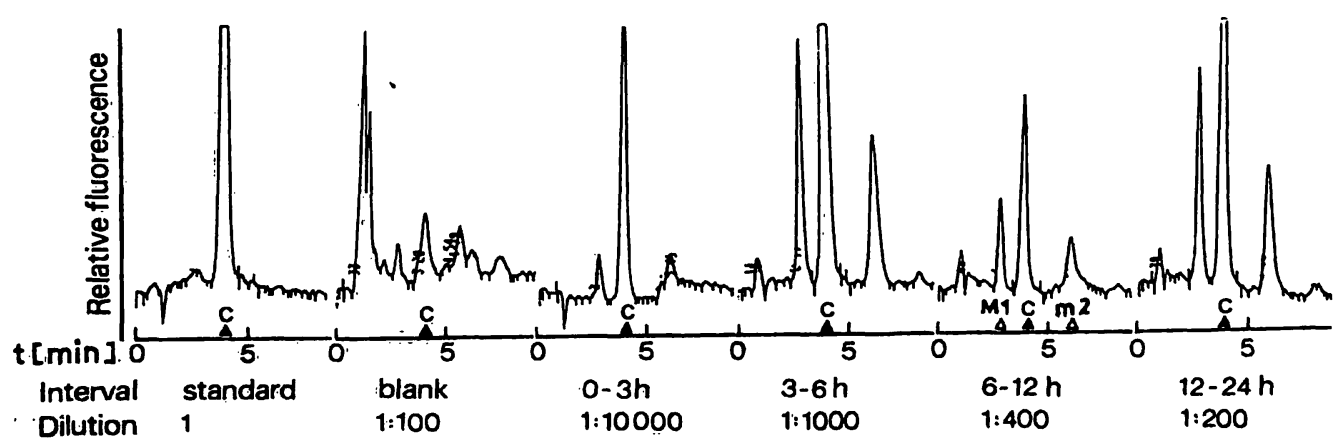

Fig. 3. Examples of chromatograms. Urine of a normal volunteer after a intravenous oral dose of $100 \mathrm{mg}$ ciprofloxacin. Separation of ciprofloxacin (C), M1 and $\mathrm{m} 2$ by method $A$.

$t=$ retention time; the interval indicated below each chromatogram refers to sampling period after intake of the drug; Dilution = sample dilution. 
Tab. 1. Retention times of ciprofloxacin and various fluorescent compounds. Method A.

\begin{tabular}{lll}
\hline Compound & $\begin{array}{l}\text { Retention time } \\
\text { (min) }\end{array}$ & $\begin{array}{l}\text { Relative } \\
\text { retention time }\end{array}$ \\
\hline Tryptophan & 1.44 & 0.40 \\
Metabolite M1 & 2.54 & 0.71 \\
Ciprofloxacin & 3.60 & 1.00 \\
Tyrosin & 3.87 & 1.08 \\
Metabolite m2 & 5.72 & 1.59 \\
Paracetamol & 6.32 & 1.76 \\
Doxycyclin & 8.10 & 2.25 \\
Metamizole & 26.59 & 7.39 \\
Salicylic acid & 34.80 & 9.67 \\
\hline
\end{tabular}

Retention times are relative to ciprofloxacin.

fractions collected after chromatography by UV spectroscopy and by demonstration of antibacterial activity, and also by addition of pure substances to the sample.

\section{Linearity and sensitivity}

Detection limits of ciprofloxacin by method A estimated from the smallest detectable area by the integrator - were $10 \mu \mathrm{g} / 1$ in serum and $200 \mu \mathrm{g} / 1$ in urine at the most sensitive setting of the fluorimeter. Detector response measured by peak areas was linearly proportional to concentration over a range of 1 to 100 . For very low concentrations the injection volume could be increased from 20 to $50 \mu l$ without distortion of the chromatogram. The detection limit of M3 by method B was $1 \mathrm{mg} / 1$ in urine.

\section{Precision and accuray}

Within-batch precision was measured in two serum pools, each in 10 replicates. Coefficients of variation were $0.8 \%(c=1.45 \mathrm{mg} / \mathrm{l})$ and $2.4 \%(c=0.42 \mathrm{mg} / \mathrm{l})$ for the complete protocol. For additional results see table 2. Between-batch precision was also measured in several serum and urine pools. Results are summarised in table 3. For serum concentrations of ciprofloxacin between 0.35 and $2.2 \mathrm{mg} / 1$ coefficients of variation varied from 4.8 to $9.3 \%$ and for urine samples coefficients of variation were between 2.4 and $7.2 \%$. The average recovery of ciprofloxacin from 24 spiked drug-free sera was $94.5 \pm 2.6 \%$ of the added concentration $(c=1.875 \mathrm{mg} / \mathrm{l})$. In another two series of 12 and 9 sera, the mean recoveries were $97.2 \pm 1.1 \%$ and $95.0 \pm 1.8 \%$. Recovery of ciprofloxacin from spiked urine was $99.6 \%$.

\section{Comparison of methods}

In several hundred samples from healthy volunteers concentrations of ciprofloxacin were determined both by chromatography and a conventional microbiological assay. Results of bivariate regression analysis and of the sign test of paired differences are summarised in table 4. Examples of representative data sets are shown in figures 5 and 6 . With the exception of two data sets obtained after a low dose (50 $\mathrm{mg}$, urine) all bioassay results were significantly higher than the results obtained by chromatography.
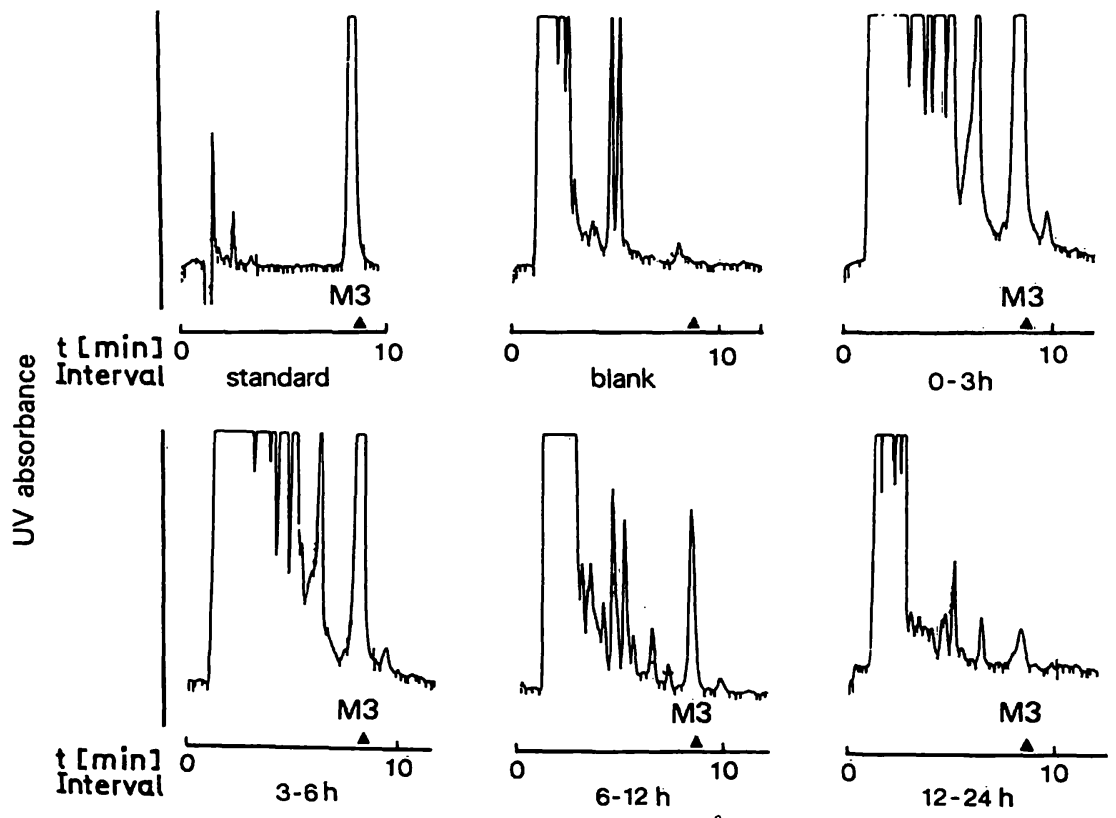
Fig. 4. Examples of chromatograms. Urine of a normal volunteer after a single oral dose of 250 mg ciprofloxacin. Determination
of metabolite $\mathrm{M3}$ by method $\mathrm{B}$.

$t=$ retention time; the interval indicated below each chromatogram refers to sampling period after intake of the drug. 
Tab. 2. Within-batch precision of method $\mathbf{A}$.

\begin{tabular}{lllcc}
\hline Material & Component & N & $\overline{\mathbf{x}}(\mathrm{mg} / \mathbf{l})$ & CV $(\%)$ \\
\hline Serum & ciprofloxacin & 10 & 1.45 & 0.8 \\
Serum & ciprofloxacin & 10 & 0.42 & 2.4 \\
Serum & metabolite M1 & 10 & 0.010 & 6.9 \\
Serum & metabolite m2 & 11 & $(0.047)$ & 25.8 \\
Urine & ciprofloxacin & 10 & 209.0 & 2.1 \\
Urine & ciprofloxacin & 10 & 29.4 & 1.7 \\
Urine & metabolite M1 & 10 & 6.2 & 5.5 \\
Urine & metabolite M1 & 10 & 1.4 & 1.9 \\
Urine & metabolite m2 & 10 & $(79.9)$ & 2.1 \\
Urine & metabolite m2 & 10 & $(18.2)$ & 3.2 \\
\hline
\end{tabular}

Concentrations of $\mathrm{m} 2$ are only given in fluorescence equivalents relative to ciprofloxacin (figures in brackets).
Tab. 3. Between-batch precision of method A.

\begin{tabular}{llccc}
\hline Material & Component & $\mathrm{N}$ & $\overline{\mathrm{x}}(\mathrm{mg} / \mathrm{l})$ & $\mathrm{CV}(\%)$ \\
\hline Serum & ciprofloxacin & 10 & 1.79 & 4.8 \\
Serum & ciprofloxacin & 10 & 0.40 & 6.0 \\
Serum & ciprofloxacin & 13 & 1.84 & 7.4 \\
Serum & ciprofloxacin & 12 & 0.41 & 8.3 \\
Serum & ciprofloxacin & 5 & 2.24 & 9.3 \\
Serum & ciprofloxacin & 11 & 0.57 & 7.6 \\
Serum & ciprofloxacin & 14 & 0.33 & 6.0 \\
Urine & ciprofloxacin & 19 & 118.8 & 2.4 \\
Urine & ciprofloxacin & 15 & 2.26 & 7.2 \\
Urine & metabolite M1 & 18 & 16.4 & 12.0 \\
Urine & metabolite M1 & 16 & 1.04 & 8.4 \\
Urine & metabolite m2 & 15 & $(17.2)$ & 12.9 \\
Urine & metabolite m2 & 15 & $(0.92)$ & 16.6 \\
\hline
\end{tabular}

Concentrations of $\mathrm{m} 2$ are only given in fluorescence equivalents relative to ciprofloxacin (figures in brackets).

Tab. 4. Comparison of methods. HPLC (x) versus bioassay (y). Statistical evaluation.

\begin{tabular}{|c|c|c|c|c|c|c|}
\hline \multirow{2}{*}{$\begin{array}{l}\text { Dose } \\
\text { mg }\end{array}$} & \multirow[t]{2}{*}{$\mathbf{N}$} & \multirow{2}{*}{$\begin{array}{l}\text { HPLC } \\
\overline{\mathbf{x}}(\mathrm{mg} / \mathrm{l})\end{array}$} & \multirow{2}{*}{$\begin{array}{l}\text { Bioassay } \\
\overline{\mathbf{x}}(\mathrm{mg} / \mathrm{l})\end{array}$} & \multirow{2}{*}{$\begin{array}{l}\text { Sign test } \\
\text { p }\end{array}$} & \multicolumn{2}{|c|}{ Bivariate regression analysis } \\
\hline & & & & & a (mg/l) & b \\
\hline Urine & & & & & & \\
\hline $\begin{array}{l}50 \text { p. o. } \\
50 \text { i. v. } \\
100 \text { p. o. } \\
100 \text { i. v. } \\
250 \text { p. o. } \\
250 \text { p. o. } \\
750 \text { p. o. }\end{array}$ & $\begin{array}{l}48 \\
48 \\
48 \\
46 \\
40 \\
40 \\
48\end{array}$ & $\begin{array}{r}18 \\
35 \\
49 \\
80 \\
193 \\
112 \\
297\end{array}$ & $\begin{array}{r}22 \\
38 \\
63 \\
98 \\
252 \\
175 \\
375\end{array}$ & $\begin{array}{l}>0.20 \\
>0.20 \\
<0.01 \\
<0.01 \\
<0.01 \\
<0.01 \\
<0.001\end{array}$ & $\begin{array}{l}-1.4 \\
+1.3 \\
-3.3 \\
+2.2 \\
+9.2 \\
+0.7 \\
-0.6\end{array}$ & $\begin{array}{l}1.290 \\
1.042 \\
1.359 \\
1.196 \\
1.262 \\
1.556 \\
1.264\end{array}$ \\
\hline \multicolumn{7}{|l|}{ Serum } \\
\hline $\begin{array}{l}50 \text { i. v. } \\
100 \text { p. } 0 . \\
100 \text { i. v. } \\
250 \text { p. } 0 . \\
750 \text { p. } 0 .\end{array}$ & $\begin{array}{l}202 \\
178 \\
201 \\
160 \\
166\end{array}$ & $\begin{array}{l}0.232 \\
0.212 \\
0.537 \\
0.532 \\
1.197\end{array}$ & $\begin{array}{l}0.255 \\
0.239 \\
0.598 \\
0.660 \\
1.543\end{array}$ & $\begin{array}{l}<0.05 \\
=0.05 \\
<0.01 \\
<0.01 \\
<0.001\end{array}$ & $\begin{array}{r}-0.002 \\
-0.019 \\
-0.010 \\
-0.036 \\
+0.023\end{array}$ & $\begin{array}{l}1.107 \\
1.213 \\
1.134 \\
1.309 \\
1.271\end{array}$ \\
\hline
\end{tabular}

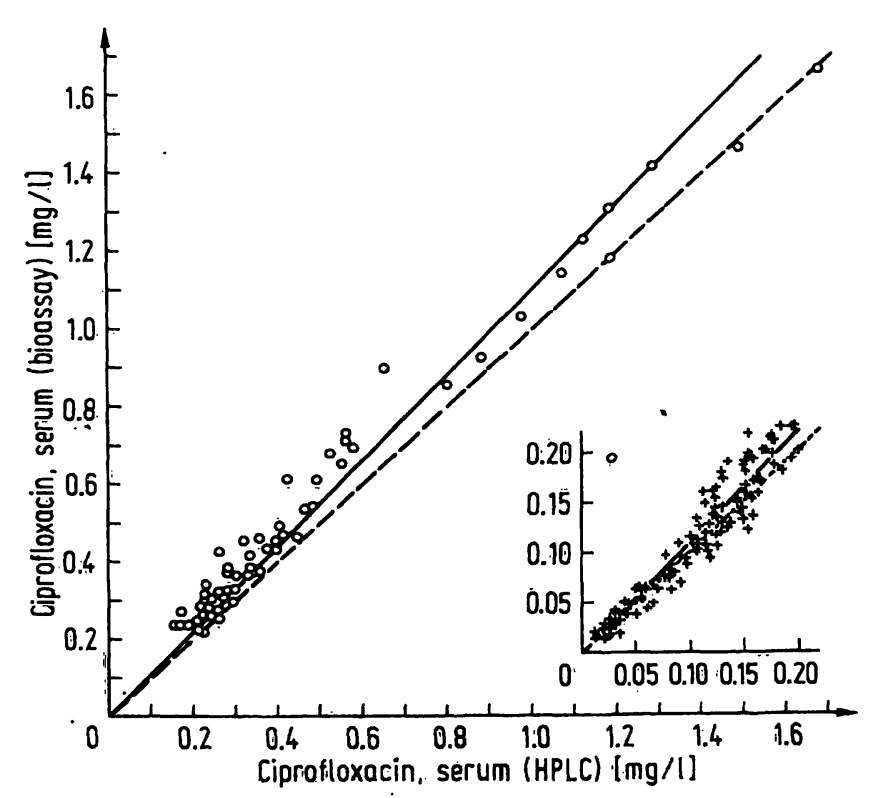

Fig. 5. Comparison of methods. Ciprofloxacin in serum after a single intravenous dose of $50 \mathrm{mg}$. Bivariate regression analysis: $y$ (bioassay) $=1.107 x$ (HPLC) $+0.002 \mathrm{mg} / \mathrm{l}$.

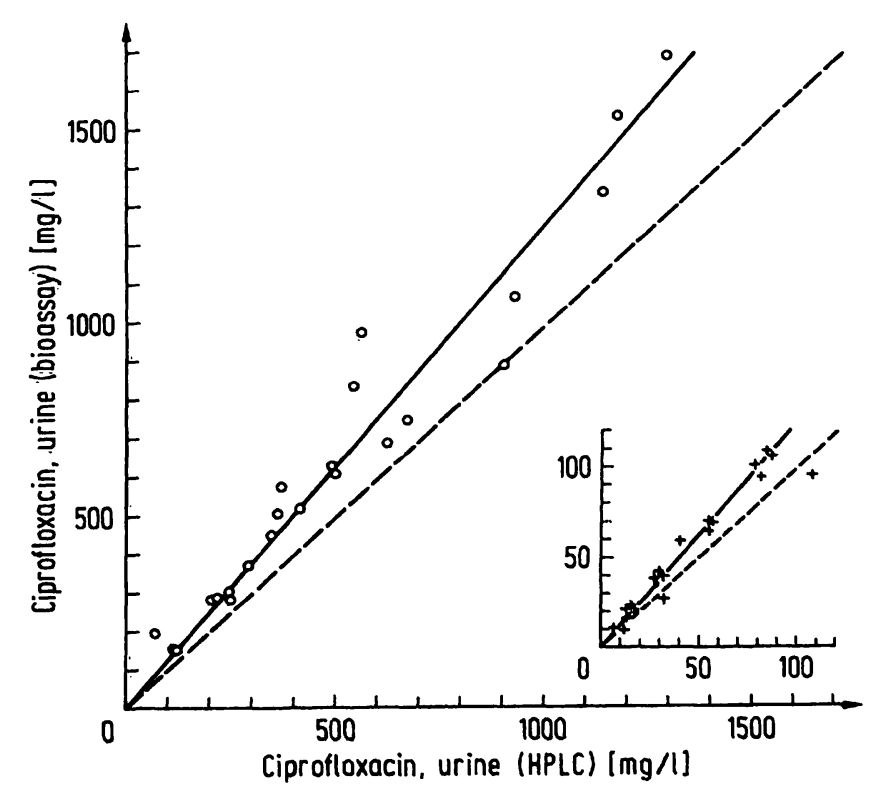

Fig. 6. Comparison of methods. Ciprofloxacin in urine after a single oral dose of $750 \mathrm{mg}$. Bivariate regression analysis: $y$ (bioassay) $=1.264 x$ (HPLC) $-0.6 \mathrm{mg} / \mathrm{l}$. 


\section{Interferences}

Up to now, ciprofloxacin has been determined in more than 2000 samples, serum and urine, from healthy volunteers without any interference. In another study on 60 patients there was only one unexplained analytical interference in a patient with terminal renal insufficiency, who had received several other drugs simultaneously.

\section{Discussion}

Ciprofloxacin is a very potent antimicrobial agent as compared with other groups of antibiotics $(1-8)$. E. g., MIC90 values of 0.015 to $2 \mathrm{mg} / 1$ were reported for several Gram-negative species (2). Thus, a fairly sensitive method was required for its determination in human body fluids. Furthermore it had to be taken into accoun' that ciprofloxacin is partially metabolised by the human organism $(9,10)$. Some of its metabolites still showed activity in the microbiological assay used. Metabolites can also interfere in chromatographic methods. The chemical structures of three metabolites have so far been identified (cf. fig. 1) (14). Another metabolite is at present under investigation by co-workers of the manufacturer. This paper shows an additional possible metabolite called $\mathrm{m} 2$ the structure of which is unknown at present (cf. figs. 2 and 3). Metabolite M4 could not be detected in urine. According to 1 . c. (14) its renal excretion is less than $1 \%$ of the dose.

Method A uses fluorescence detection for high sensitivity and better specificity. It differs from a method first described by $G a u(15)$ in the method of deproteinisation, the stationary phase and completeness of separation. During the preparation of the manuscript similar chromatographic methods for ciprofloxacin have been published $(16-18)$, none of which deals with the quantitation of the metabolites. The present method A separated ciprofloxacin from all known metabolites (cf. figs. 2 and 3). It was sufficiently sensitive to measure serum concentrations up to $24 \mathrm{~h}$ after administration of a single oral dose of $250 \mathrm{mg}$.
Precision and recovery were satisfactory. Since the quantum yield of the metabolites differs considerably from that of the parent compound, calibration of the fluorescence detector with pure reference substances is essential. The poor precision obtained with metabolite $\mathrm{m} 2$ in serum (tab. 2) was probably due to the rather small signal relative to the parent compound to which the fluorometric detector was adjusted (cf. fig. 2).

Method B was developed for the main metabolite M3 (oxo-ciprofloxacin), which yielded low fluorescence and was less polar (cf. fig. 4).

Results of the microbiological assay performed with split samples were generally somewhat higher than results obtained by chromatography (tab. 4). The differences were more pronounced in urine than in serum. This is likely to be due to the presence of metabolites with antimicrobial activity, the concentration of which is usually higher in urine than in serum. In one trial a single oral dose of $250 \mathrm{mg}$ ciprofloxacin was given to 10 volunteers. The mean renal elimination within $24 \mathrm{~h}$ was ciprofloxacin 33.6 $\pm 8.0 \%$ of the dose, metabolite M1 $1.3 \pm 0.5 \%$ and metabolite M3 $5.5 \pm 8.0 \%$ (11). Metabolite M3 had an activity of $74 \%$ relative to ciprofloxacin. Similar differences between microbiological and chromatographic results were reported for urine (16) and for bile (18). For this reason liquid chromatography appears the more specific method for ciprofloxacin and is recommended both for pharmacokinetic studies and therapeutic drug monitoring. For the latter application some caution is warranted in patients on concomitant treatment with drugs that also fluoresce. Since clinical experience with ciprofloxacin is presently still limited, indications for routine therapeutic drug monitoring are not yet defined. Possible indications might be high dose therapy in severe infections and/or reduced elimination capacity in renal or hepatic disease.

\section{Acknowledgement}

The excellent technical assistance of Mrs. H. Hartwig and Mrs. G. Dzwillo is gratefully acknowledged.

\section{References}

1. Bàuernfeind, A. \& Petermüller, C. (1983) Europ. J. Clin. Microbiol. 2, 111-115.

2. Wise, R., Andrews, J. M. \& Edwards, L. J. (1983) Antimicrob. Agents Chemother. 23, 559-564.

3. Chin, N.-X. \& Neu, H. (1984) Antimicrob. Agents Chemother. $25,319-326$.

4. Eliopoulos, G. M., Gardella, A. \& Moellering, R. C. (1984) Antimicrob. Agents Chemother. 25, 331-335.

5. Barry, A. L., Jones, R. N., Thornsberry, C., Ayers, L. W., Gerlach, E. H. \& Sommers, H. M. (1984) Antimicrob. Agents Chemother. 25, 633-637.

6. Shrire, L., Saunders, J., Traynor, R. \& Koornhof, H.J. (1984) Eur. J. Clin. Microbiol. 3, 328-332.

7. Hoogkamp-Konstanje, J. A. A. (1984) Eur. J. Clin. Microbiol. $3,333-338$

8. Zeiler, H.-J. \& Grohe, K. (1984) Eur. J. Clin. Microbiol. $3,339-343$. 
9. Borner, K., Höffken, G., Prinzing, C. \& Lode, H. (1984) Fortschr. Antimikr. Antineoplast. Chemother. 3-5, 695-699.

10. Höffken, G., Borner, K., Glatzel, P. D., Koeppe, P. \& Lode, H. (1985) Eur. J. Clin. Microbiol. 4, 345-345.

11. Borner, K., Höffken, G., Lode, H., Koeppe, P., Prinzing, C., Glatzel, P., Wiley, R., Olschewski, P., Sievers, R. \& Reinitz, D. (1986) Eur. J. Clin. Microbiol. in press.

12. Reeves, D. S. \& Bywater, M. F. (1976) Assay of antimicrobial agents. In: Selected topics in bacteriology (de Louvois, J. ed.) London, pp. $21-78$.

13. Averdunk, R. \& Borner, K. (1970) Z. Klin. Chem. Klin. Biochem. 8, 263-268.
14. Zeiler, H.-J., Gau, W. \& Petersen, U. (1984) 24th Interscience Conference on Antimicrobial Agents, Washington, D. C., USA. Abstract.

15. Gau, W., Ploschke, H. J., Schmidt, K. \& Weber, B. (1985) J. Liquid Chromatography 8, 485-497.

16. Joos, B., Ledergerber, B., Flepp, M., Bettex, J.-D., Lüthy, R. \& Siegenthaler, W. (1985) Antimicrob. Agents Chemother. 27, 353-356.

17. Weber, A., Chaffin, D., Smith, A. \& Opheim, K. E. (1985) Antimicrob. Agents Chemother. 27, 531-534.

18. Brogard, J.-M., Jehl, F., Monteil, H., Adloff, M., Blickle, M.-F. \& Levy, P. (1985) Antimicrob. Agents Chemother. $28,311-314$.

Prof. Dr. K. Borner

Institut für Klinische Chemie

und Klinische Biochemie

Hindenburgdamm 30

D-1000 Berlin 45 
